\title{
A Novel Approach for Controlled Pollination in Casuarina equisetifolia
}

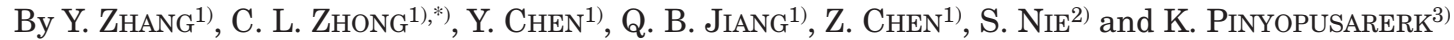

(Received $8^{\text {th }}$ August 2013)

\begin{abstract}
Casuarina equisetifolia is an important tree species in the tropical and subtropical zones of Asia, Africa and the Pacific. There is an increasing interest in producing intra- and inter-specific hybrids of casuarina species. Conventional bagging controlled pollination method yielded very low fruit set and poor seed germination. High temperature and humidity in the pollination bags appeared to have instigated unfavorable conditions for pollination and fertilization mechanism. In this study, a novel approach was developed by conducting pollination in closed chambers which functioned like pollination bags. Fruit set and seed germination rate increased from $7.0 \%$ to $89.9 \%$, and $8.1 \%$ to $51.8 \%$ respectively compared with the conventional bagging controlled pollination method. Based on the results, a controlled pollination glasshouse with 10 separated chambers has been designed to produce multiple hybrid combinations in a single pollination procedure.
\end{abstract}

Key words: Casuarina equisetifolia, cross breeding, controlled pollination, fruit set, seed germination rate, pollination chambers.

\section{Introduction}

Casuarina equisetifolia L. (Casuarinaceae) is a nitrogen-fixing tree native to Southeast Asia, Australia and Pacific islands (PInYopusarerk and House, 1993). The species is of considerable social, economic and environmental importance in the tropical and subtropical regions of the world. In southern China, nearly all of the estimated 300,000 hectares of casuarina plantations is comprised of $C$. equisetifolia (ZHONG et al., 2011). In India, over two-thirds of the total 500,000 hectares of casuarina plantations are established with this species (RAWAT et al., 2011). Genetic improvement programs for C. equisetifolia are actively underway in China and India.

Hybridization in plants can provide a rapid means for increasing genetic variation and producing novel gene combinations which can, in turn, potentially produce the hybrid vigor in growth or resistance. The importance of intra- and inter-specific hybridization for genetic improvement of forest trees has been evident for at least 50 years (ZOBEL and TALBERT, 2003), and controlled crossing has been an increasingly important method to concentrate the best alleles from a range of selected

\footnotetext{
1) Research Institute of Tropical Forestry, CAF, Guangzhou 510520, P. R. China.

2) Fujian Academy of Forestry, Fuzhou 350012, P. R. China.

3) CSIRO Plant Industry, GPO Box1600, ACT 2601, Australia.

*) Corresponding author: C. L. ZHong. Tel. +86-20-87030939. E-Mail: zcl@ritf.ac.cn
}

trees and obtain genetic gain for tree breeding (HARBARD et al., 1999).

Conventionally, controlled pollination of forest tree is conducted manually in the field. Bagging of the flowers is used to exclude undesired pollens. Scaffoldings are required when pollinating flowers in the tall trees. The scaffoldings which are erected using steel pipes are expensive.

Bamboo scaffoldings are often used in China but they are easily damaged by frequent typhoons in the coastal area. In casuarinas, very poor fruit set $(<1 \%)$ and low seed germination rate obtained from conventional controlled pollination has been reported in India (NICODEMUS et al., 2011). Thus, the use of conventional method for controlled pollination of casuarinas is inefficient and costly.

Grafting is used in agriculture and forestry to induce dwarfing of tree to facilitate pollination practice, and to accelerate the onset of flowering, which in turn shortens the breeding cycle (PEREz et al., 2007; DARIKOvA et al., 2011). Our experiences with casuarina species, such as C. equisetifolia, C. cunninghamianaand, C. glauca indicate that grafted plants with physiologically mature scions flower in the following season, which offers a precondition for developing a new approach for controlled pollination in casuarinas (ZHANG, 2013).

The objective of this study was to develop a more efficient method for controlled pollination in casuarinas using grafted plants of $C$. equisetifolia.

\section{Materials and Methods}

The experiment was conducted at Chihu Forest Farm nursery in Huian county, Fujian province of China. The nursery site was surrounded by mature $C$. equisetifolia plantations from which scions and male pollen were collected for this experiment.

\section{Propagation of grafted plants}

In March 2009, scions of male and female trees from a 20-year-old C. equisetifolia seedling plantation were grafted on stock plants grown in containers $(35 \mathrm{~cm}$ diameter and $25 \mathrm{~cm}$ deep). The grafted plants were about $100 \mathrm{~cm}$ tall when the controlled pollination experiment commenced in April 2010.

\section{Pollination methods}

Three pollination methods were carried out in three replicates of four grafted female plants each as follows.

Method 1 - conventional bagging: Twelve grafted female plants with visible flower buds were laid out on an open ground. They were arranged into three groups 
Table 1. - Mean fruit set, number of seeds per cone and seed germination rate of three pollination methods in C. equisetifolia.

\begin{tabular}{lccc}
\hline Pollination method & $\begin{array}{c}\text { Fruit set } \\
(\%)\end{array}$ & $\begin{array}{c}\text { Number of seeds per } \\
\text { cone }\end{array}$ & $\begin{array}{c}\text { Seed germination } \\
(\%)\end{array}$ \\
\hline 1. Conventional bagging & $7.0 \pm 6.2^{\mathrm{c}}$ & $68.3 \pm 13.3^{\mathrm{b}}$ & $8.1 \pm 5.9^{\mathrm{c}}$ \\
2. Pollination chambers & $89.9 \pm 12.0^{\text {a }}$ & $81.8 \pm 16.1^{\mathrm{a}}$ & $51.8 \pm 10.1^{\mathrm{a}}$ \\
3. Open pollination & $69.5 \pm 13.8^{\mathrm{b}}$ & $74.5 \pm 15.2^{\text {ah }}$ & $28.3 \pm 9.9^{\mathrm{h}}$ \\
\hline
\end{tabular}

Note: Data were mean $\pm \mathrm{SD}$. Data followed by the same superscript letter were not significantly different by Duncan's multiple range test $(\mathrm{P}<0.05)$.

of four $(2 \times 2)$ spaced at $1 \mathrm{~m}$ apart. On each plant, a branch was selected and tagged. All female flower buds except five to be pollinated were removed. The flower bud branches were bagged in glassine paper bags $(25 \times 15 \mathrm{~cm})$ before anthesis. When male and female flowers were in full bloom, the bags were opened, and mixed fresh pollen collected from a nearby plantation was manually pollinated on the female flowers using brushes at 8:00-10:00 am. Immediately thereafter, the pollinated flowers were rebagged to exclude undesired pollen. The manual pollination was repeated two days after. The bags were removed 15 days later after confirmation of drying and withering of the female flowers.

Method 2 - pollination chambers: Three clear plastic sheet chambers $1.5 \mathrm{~m}, 1.5 \mathrm{~m}$ and $2 \mathrm{~m}$ in length, width and height respectively were placed inside a glasshouse. These chambers functioned as pollination bags. Each chamber had a separate entrance through overlapping of two plastic sheets. Twelve grafted female plants with visible flower buds were chosen. On each plant a branch with visible flower buds was tagged. All flower buds except five to be pollinated were removed. Four grafted female plants were then placed inside each of the three chambers (as 3 replicates). When female flowers were in receptive stage, one male plant with the inflorescences shedding pollen was placed in the centre of the four female plants inside each chamber, and three male plants used for the three chambers are grafted ramets of the same individual. Male inflorescences were shaken by hand to disperse the pollen at 8:00-10:00 am. This shaking was repeated for five days. When all female flowers had withered about 15 days later, the grafted plants were moved to open area outside the glasshouse.

Method 3 - open pollination (control): The same twelve female plants in Method 1 were used. A branch with visible flowers on each plant was tagged. All flowers apart from five to be pollinated were removed. Male trees in the adjacent plantation provided a pollen source for the open pollination. In addition, ten grafted male plants obtained from different individuals were placed around the female plants to provide supplementary pollen.

\section{Monitoring of temperature and humidity}

On 25-27 April 2010, temperature and relative humidity $(\mathrm{RH})$ inside the pollination bags in Method 1 and inside the chambers in Method 2 were recorded using a mercury thermometer and a psychrometer. Simultaneously, the ambient air temperature and $\mathrm{RH}$ in the nursery area were recorded for Method 3. These measurements were taken between 8:00 am and 3:30 pm at 1.5 hours interval over the three days.

\section{Assessment and data analysis}

In November 2010 approximately five months after pollination treatments, the number of the fruits (cones) on the tagged branches was counted. The cones were

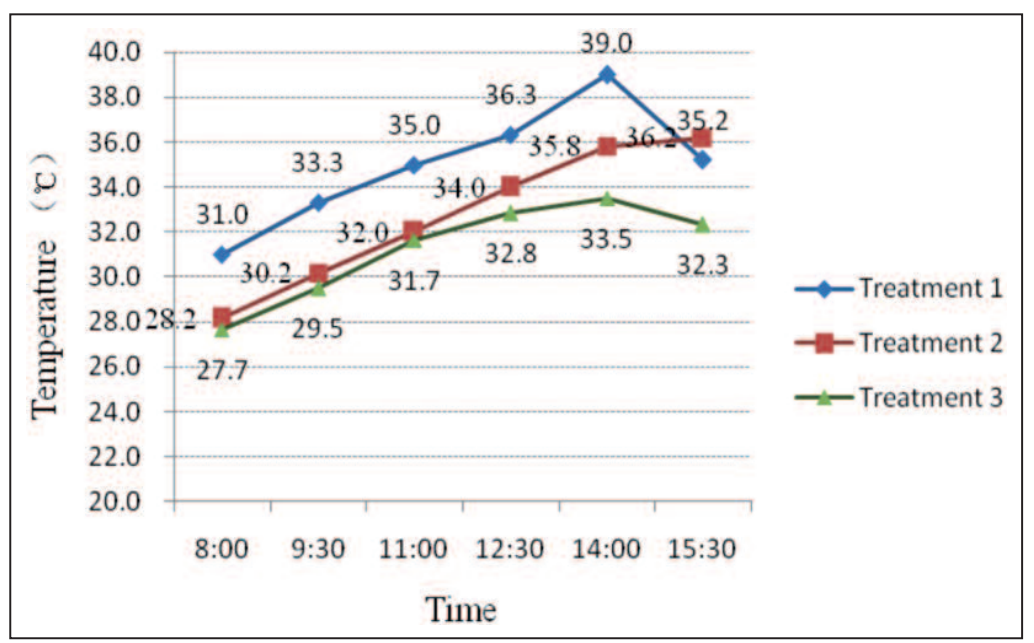

Figure 1. - Temperature inside pollination bags and chambers in Methods 1 and 2 , and ambient air temperature in Method 3. 
air-dried individually in the sun to extract the seed, after which the number of seeds in each cone was counted. All the seeds were then sown to determine the germination rate

One-way ANOVA was performed using SAS statistical package (SAS INSTITUTE INC., 1999) on the number of cones (fruit set), number of seeds per cone, and seed germination rate. Prior to ANOVA, arcsin transformations were performed for percentage data. Duncan's Multiple Range Test at $5 \%$ level was used to compare the differences between treatment means.

\section{Results}

Differences between pollination methods in fruit set, number of seeds per cone and seed germination rate

There were significant differences $(\mathrm{P}<0.05)$ between pollination methods in fruit set, number of seeds per cone and seed germination rate (Table 1).

The highest fruit set $(89.9 \%)$ was obtained by pollination in chambers (Method 2), followed by open pollination $(69.5 \%)$. The conventional bagging (Method 1) yielded very low success rate at $7 \%$ only.

Pollination in chambers also yielded the highest number of seeds per cone, average 81.8 seeds. There was no difference in the number of seeds per cone between conventional bagging (Method 1) and open pollination (Method 3). The mean values recorded for these two methods were 68.3 and 74.5 seeds respectively.

Germination was very poor $(8.1 \%)$ in the seeds obtained by the conventional bagging method. The best result $(51.8 \%)$ was again displayed by pollination in the chambers. The seeds obtained from open pollination had $28.3 \%$ germination rate.

\section{Observation of temperature and $\mathrm{RH}$ in three pollination methods}

As shown in Fig. 1, the temperature inside pollination bags in Method 1 was higher than that in Methods 2 and 3. The temperature increased steadily from $8.30 \mathrm{am}$ and reached the maximum at $2 \mathrm{pm}$. The maximum temperature was $39^{\circ} \mathrm{C}$ in Method 1 compared to $36.2^{\circ} \mathrm{C}$ and $33.5^{\circ} \mathrm{C}$ in Methods 2 and 3 respectively.

In all three pollination methods, the relative humidity $(\mathrm{RH})$ was higher in the morning and decreased steadily with time as the temperature increased (Fig. 2). As with the temperature, $\mathrm{RH}$ was higher in Method 1 (88-95\%) than that in Method $2(75.3-81.3 \%)$ and Method 3 (76.7-89\%). The differences in $\mathrm{RH}$ between Methods 2 and 3 were small.

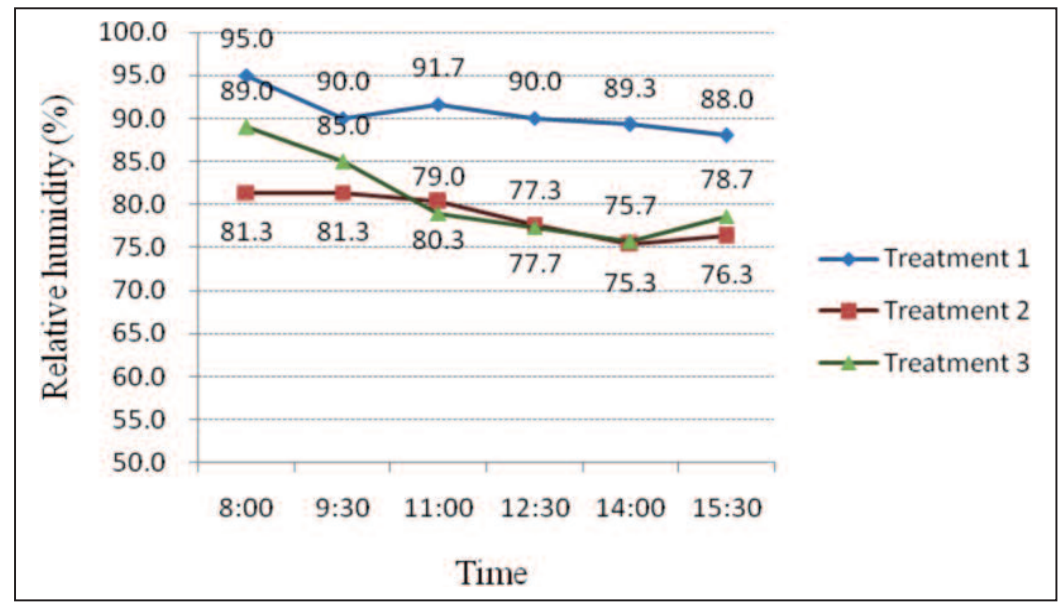

Figure 2. - Relative humidity of the three pollination methods.

\begin{tabular}{|c|c|c|c|c|}
\hline 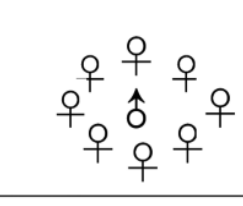 & $\begin{array}{l}\text { (8) (1) } \\
7 \text { (1) (3) } \\
\text { (6) (5) (4) }\end{array}$ & $\begin{array}{l}\text { (8) } 11 \text { (2) } \\
\text { (7) (2) (3) } \\
\text { (6) (5) (4) }\end{array}$ & $\begin{array}{l}\text { (8) (2) } \\
(7) \text { (3) (3) } \\
\text { (6) (5) (4) }\end{array}$ & $\begin{array}{l}\text { (8) (1) (2) } \\
\text { (7) (4) (3) } \\
\text { (6) (5) (4) }\end{array}$ \\
\hline $\begin{array}{l}\text { (8) } 1 \text { (2) } \\
\text { (7) (5) (3) } \\
\text { (6) (5) (4) }\end{array}$ & $\begin{array}{l}\text { (8) } 1 \text { (2) } \\
(7) \text { (6) (3) } \\
\text { (6) (5) (4) }\end{array}$ & $\begin{array}{l}\text { (8) } 1 \text { (2) } \\
\text { (7) } 7 \text { (3) } \\
\text { (6) (5) (4) }\end{array}$ & $\begin{array}{l}\text { (8) (1) (2) } \\
\text { (7) (8) (3) } \\
\text { (6) (5) (4) }\end{array}$ & $\begin{array}{l}\text { (8) (1) (2) } \\
\text { (7) (9) (3) } \\
\text { (6) (5) (4) }\end{array}$ \\
\hline
\end{tabular}

Figure 3. - Controlled pollination chambers for casuarina hybridization. 


\section{Discussion}

Generally, April and May are the main flowering period of casuarina in southern China. During this time, outdoor-temperature generally reaches $30^{\circ} \mathrm{C}$ or higher in the sun. In this experiment, the temperature inside the pollination bags was found to reach $39^{\circ} \mathrm{C}$. Such higher temperature was likely due to the "greenhouse effect". Additionally, plant transpiration in the bags in the strong sunlight would result in higher humidity than outside because of a build-up of moisture inside the bags (MONCUR, 1995). High temperature and humidity in pollination bags increase respiration and enzymatic activities of casuarina pollen, and consequently lead to rapid loss of pollen viability (GUDIN et al., 1991; WANG and LU, 2002). In our previous study, it was proved that casuarina pollen in vitro germination rate dropped from $13.2 \%$ to $0.8 \%$ after storage at room temperature $\left(25^{\circ} \mathrm{C}\right)$ for 3 days (ZHANG et al., 2011). It took at least 6 hours for pollen germination on stigma through observation of pollen tube growth using fluorescence technique (unpublished data). The high temperature and humidity in pollination bags, coupled with the long time for pollen germination, probably resulted in viability loss of most pollen grains, and subsequently led to low fruit set in the conventional bagging method. In addition, female flowers at different locations of a flower-bearing branch may not bloom simultaneously and thus they are not receptive at the same time which might also lead to low fruit set in Method 1. Therefore, hand pollinations which were done two times in this experiment might not be sufficient.

Differences in temperature and humidity between inside and outside the glasshouse were relatively slight for most of time during $8 \mathrm{am}-3.30 \mathrm{pm}$. The similar environment ensured that male and female flowers can pollinate and fertilize under favorable conditions. Female flowers of Allocasuarina verticillata (Casuarinaeae family) remain receptive for up to 12 weeks (MoNCUR et al., 1997). During this period, fresh pollen from male inflorescences could reach most receptive stigmas. This explains the higher fruit set in Methods 2 and 3 than that of Method 1.

Normally, pollination and fertilization of casuarina can be accomplished without difficulty under outdoor conditions, however, many environmental factors such as winds and rain can affect the outcome. Furthermore, low pollen density in the air reduces the chance of viable pollen landing on receptive stigma, consequently causing pollination limitation (insufficient pollen transfer by vectors) in female flowers (JENNIFER et al., 2001). In contrast, in a small and closed space of pollination chambers in Method 2, higher density of pollen shed from male inflorescences enhances more viable pollen grains to stick to receptive stigmas. This indicates the higher fruit set in Method 2 than that of open pollination in Method 3.

The majority of casuarina species are dioecious, windpollinated and primarily obligate outbreeders (BARLOW, 1981), that is an essential prerequisite for developing this pollination approach. Based on these reproductive characteristics of casuarinas, factorial mating design can be employed in casuarinas controlled pollination using the chamber approach. Many separated chambers can be used to produce inter- and intra-specific hybrids of different casuarina species (Fig. 3). Compared with conventional controlled hand pollination method, this approach can eliminate adverse effects of outdoor environments, and reduce cost of materials and labor used in conventional controlled pollination.

Explanation: The drawing (Figure 3) shows 10 separated chambers which are placed inside a glasshouse. Shade cloth can be installed on top of the glasshouse to prevent high-temperature from strong sunlight when necessary. The length, width and height of each chamber are $3.0 \mathrm{~m}, 3.0 \mathrm{~m}$ and $2 \mathrm{~m}$ respectively, and there is an independent door for every chamber. Additionally, a small electric fan is set inside the chamber to simulate anemophily during pollination. Each chamber consists of one male and eight female plants with the male being placed in the centre and surrounded by the female plants. A factorial mating design is employed for this design. Ten pollination chambers mean that up to 10 different candidate paternal parents can be used in a single pollination, and 8 different maternal parents around paternal parents in 10 chambers imply that up to 80 hybrid combinations can be obtained in a single controlled pollination procedure.

\section{Acknowledgements}

This study was financially supported by the $12^{\text {th }}$ National Five-Year Plan for Forestry Project (2012BAD01B0603), Youth Scientist Foundation of Research Institute of Tropical Forestry (RITFKYYW2010-11, 2007-24), and Science and Technology Innovation Project of Guangdong Forestry (2010KJCX009-01, 2011KJCX018-01).

\section{References}

BARlOW, B. A. (1981): Casuarinas - a taxonomic and biogeographic review, pp. 10 - 18. In: Casuarina ecology management and utilization, edited by S. J. Midgley, J.W. Turnbull and R. D. Johnson. CSIRO: Canberra.

Darikova, J. A., Y. V. Savva, E. A. Vaganov, A. M. Grachev and G. V. KuZnetsova (2011): Grafts of woody plants and the problem of incompatibility between scion and rootstock (a review). Journal of Siberian federal university, Biology 1, 4: 54-63.

Gudin, S., L. Arene and C. Pellegrino (1991): Influence of temperature and hygrometry on rose pollen germination. Advances of Horticulture Science 5: 96-98.

HARBARD, J. L., A. R. Griffin and J. Espego (1999): Mass controlled pollination of Eucalyptus globulus: a practical reality. Canadian Journal of Forest Research 29(10): 1457-1463.

LI, R. F. and J. C. HuANG (2011): Important roles of casuarinas in coastal shelterbelt construction in Hainan province, pp. 220-224. In: Improving smallholder livelihoods through improved casuarina productivity: Proceedings of the $4^{\text {th }}$ international casuarinas workshop, edited by C. L. Zhong, K. PinYoupusarerk, A. KalinGANIRE and C. Franche. Beijing, China. 
Jennifer, M., M. Weis and J. S. HeYwood (2001): Pollination limitation to reproductive success in the Missouri evening primrose. Oenothera macrocarpa (Onagraceae). Amer. J. Bot. 88(9): 1615-1622.

Moncur, M. W. (1995): Techniques for pollinating Eucalypts. ACIAR Technical Reports, No. 34. 20p.

Moncur, M. W., D. J. Boland and J. L. Harbard (1997): Aspects of the floral biology of Allocasuarina verticillata (Casuarinaceae). Aust. J. Bot. 45: 857-869.

Nicodemus, A., Y. C. SAgaria, K. Kannan, R. Rangarajan, Mohanty and B. G. SINGH (2011): Production of interprovenance and inter-specific hybrids of Casuarina equisetifolia and $C$. junghuhniana and their early evaluation for growth and form traits, pp. 61-67. In: Improving smallholder livelihoods through improved casuarina productivity: Proceedings of the $4 \mathrm{t}^{\mathrm{h}}$ international casuarinas workshop, edited by C. L. ZHONG, K. Pinyoupusarerk, A. Kalinganire and C. Franche. Beijing, China.

Perez, A. M, T. L. White, D. A. Huber and T. A. Martin (2007): Graft survival and promotion of female and male strobili by top grafting in a third-cycle slash pine (Pinus elliottii var. elliottii) breeding program. Can. J. For. Res. 37: 1244-1252.

Pinyopusarerk, K. and A. P. N. House (1993): Casuarina: an annotated bibliography of $C$. equisetifolia, C. junghuhniana and C. oligodon. ICRAF, Nairobi, Kenya.

PINYOPUSARERK, K. (1999): Report on a technical advisory visit to the People's Republic of China. ACIAR technical reports, No. 673, Canberra.

Pinyopusarerk, K., A. Kalinganire, E. R. Williams and K. M. AKEN (2004): Evaluation of international provenance trials of Casuarina equisetifolia. ACIAR technical reports, No. 58, Canberra.
Rawat, G. S., N. K. Kumar and A. Nicodemus (2011): Research and Development of Casuarinas in India, pp 5-10. In: Improving smallholder livelihoods through improved casuarina productivity: Proceedings of the $4^{\text {th }}$ international casuarinas workshop, edited by C. L. Zhong, K. Pinyoupusarerk, A. KalinganiRe and C. Franche. Beijing, China.

WANG, Q. L. and L. D. LU (2002): Pollen preservation and its viability test. Chinese Bulletin of Botany, 19(3): 365-373.

SAS SOFTWARE RELEASE 8.2 (1999): SAS Institute Incorporated, SAS Circle, Box 8000, Cary, NC, USA.

ZHANG, Y. (2013): Studies on Genetic Improvement of Three Casuarina Species. Ph.D. thesis.

Zhang, Y., C. Wu, C. L. Zhong, Q. B. JiAng and K. PinYoPUSARERK (2011): Effects of medium components and storage conditions on pollen germination of Casuarinas equisetifolia under in vitro conditions, pp. 95-101. In: Improving smallholder livelihoods through improved casuarina productivity: Proceedings of the $4^{\text {th }}$ inter national casuarinas workshop, edited by C. L. ZHONG, K. Pinyoupusarerk, A. Kalinganire and C. Franche. Beijing, China.

Zhong, C. L., Y. Zhang, Y. Chen, Q. B. Jiang, Z. Chen, C. Wu, K. Pinyopusarerk, C. Francheand and D. Bogusz (2011): Casuarina research and development in China, pp 5-10. In: Improving smallholder livelihoods through improved casuarina productivity: Proceedings of the $4^{\text {th }}$ international casuarinas workshop, edited by C. L. Zhong, K. Pinyoupusarerk, A. Kalinganire and C. Franche. Beijing, China.

Zobel, B. and J. TALBERT (2003): Applied forest tree improvement. Blackburn Press, Caldwell.

Herausgeber: Johann Heinrich von Thünen-Institut. Bundesforschungsinstitut für Ländliche Räume, Wald und Fischerei. Schriftleitung: Institut für Forstgenetik, Sieker Landstrasse 2, D-22927 Grosshansdorf Verlag: J. D. Sauerländer's Verlag, Berliner Strasse 46, D-63619 Bad Orb Anzeigenverwaltung: J. D. Sauerländer's Verlag, Bad Orb

Gesamtherstellung: PPPP Norbert Wege e.K., Gladenbach — Printed in Germany. 